\title{
NATURALIZATION AND EXPATRIATION
}

\author{
Richard W. Fiournoy, JR. \\ Assistant Solicitor, Department of State
}

Within the limits of this short article it will obviously be impossible even to touch upon, much less to discuss, all of the questions which arise under the subjects of naturalization and expatriation. I shall confine myself to a brief discussion of some of their outstanding features, with particular regard to the questions of domicil and diplomatic protection, and in this relation shall give special attention to the provisions of section 2 of the Expatriation Act of March 2, I907, and section I5 of the Naturalization Act of June 29, I906. ${ }^{2}$

The great movement of population in recent years from southern and eastern Europe to the United States, and the additional impetus given to this movement by the debacle of the World War have brought the subjects of naturalization and expatriation and the allied subject of . immigration, that is, the whole citizenship problem, into special prominence. While in the present article it will be impossible to make more than brief allusions to the extremely important subjects of immigration, and while it will be possible to enter into a discussion of certain phases only of the subjects of naturalization and expatriation, their relation to the broader problem should be borne in mind.

It may be desirable to review briefly the early history of our legislation concerning naturalization. Before the adoption of the Constitution of the United States the several States of the Confederation had naturalized aliens according to their individual laws, which varied considerably; but article I, section 8 of the Constitution authorized Congress "to establish an uniform Rule of Naturalization." On March 26, I790, Congress passed the first national law of naturalization, the first section of which read as follows: ${ }^{3}$

"That any alien, being a free white person, who shall have resided within the limits and under the jurisdiction of the United States for the term of two years, may be admitted to become a citizen thereof, on application to any common law court of record, in any one of the states wherein he shall have resided for the term of one year at least, and making proof to the satisfaction of such court, that he is a person of good character, and taking the oath or affirmation prescribed by law, to support the constitution of the United States which oath or affirmation such court shall administer; and the clerk of such court shall record such application, and the proceedings thereon; and thereupon such person shall be considered as a citizen of the United States."

${ }^{2} 34$ Stat. at L. I228.

${ }^{2}$ Ibid. 596, 6or.

${ }^{3}$ I ibid. I03. 
The debate in Congress leading up to the adoption of this statute is quite interesting. It related principally to the question of the length of residence in the United States to be required before naturalization. The debate opened on the third of February, I790. The original bill provided for a partial naturalization, conferring all rights of citizenship except the right to hold public office, after a residence of one year, and full naturalization after a residence of two years. Mr. Tucker of South Carolina moved the elimination of the one-year requirement, because "he conceived it the policy of America to enable foreigners to hold land in their own right in less than one year," although he had no objection to extending the period of residence required as a preliminary to complete naturalization to as much as three years. ${ }^{4}$

Mr. Page of Virginia, who seems to have been one of the original proponents of the "melting pot" theory, was in favor of adopting a most liberal policy toward immigrants. ${ }^{5}$

"I think," said he, "we shall be inconsistent with ourselves, if, after boasting of having opened an asylum for the oppressed of all nations, and established a Government which is the admiration of the world, we make the terms of admission to the full enjoyment of that asylum so hard as is now proposed. It is nothing to us whether Jews or Roman Catholics settle amongst us; whether subjects of Kings or citizens of free States wish to reside in the United States, they will find it their interest to be good citizens, and neither their religious nor political opinions can injure us, if we have good laws, well executed."

Mr. Hartley of Pennsylvania was among those who took a stricter view. ${ }^{6}$

"He had no doubt of the policy of admitting aliens to the rights of citizenship; but he thought some security for their fidelity and allegiance was requisite besides the bare oath; that is, he thought an actual residence of such a length of time as would give a man an opportunity of esteeming the Government, from knowing its intrinsic value, was essentially necessary to assure us of a man's becoming a good citizen."

Mr. White of Virginia was of a like mind with Mr. Hartley. It is interesting to note that at that early day he foresaw the importance of providing a definite rule of expatriation for cases of aliens who might take advantage of the proposed liberal law to procure naturalization for

"I Amnals, Ist Cong. Irog.

"Ibid. Irro. The need of workers to assist in the development of the vast, unreclaimed wilderness in the west furnished a strong argument in favor of liberal rules governing immigration and naturalization. Moreover, it should be remembered that one of the charges against George III in the Declaration of Independence was that he had "endeavoured to, prevent the population of these States; for that purpose obstructing the Laws for Naturalization of Foreigners; refusing to pass others to encourage their migration hither, and raising the conditions of new Appropriations of Lands."

'Ibid. IIog. 
the immediate advantage which it would give, and then resume their foreign domicil. ${ }^{7}$

"Foreign merchants and captains of vessels might by this means evade the additional duties laid on foreign vessels; he thought, therefore, if the words were struck out, that another clause ought to be added, depriving persons of the privilege of citizenship, who left the country and staid abroad for a given length of time."

The acute and far-seeing Madison was quick to see the point raised by Mr. White. He spoke as follows: ${ }^{8}$

"When we are considering the advantages that may result from an easy mode of naturalization, we ought also to consider the cautions necessary to guard against abuses. It is no doubt very desirable that we should hold out as many inducements as possible for the worthy part of mankind to come and settle amongst us, and throw their fortunes into a common lot with ours. But why is this desirable? Not merely to swell the catalogue of people. No, sir, it is to increase the wealth and strength of the community; and those who acquire the rights of citizenship, without adding to the strength or wealth of the community, are not the people we are in want of. And what is proposed by the amendment is, that they shall take nothing more than an oath of fidelity, and declare their intention to reside in the United States. Under such terms, it was well observed by my colleague, aliens might acquire the right of citizenship, and return to the country from which they came, and evade the laws intended to encourage the commerce and industry of the real citizens and inhabitants of America, enjoying at the same time all the advantages of citizens and aliens.

"I should be exceedingly sorry, sir, that our rule of naturalization excluded a single person of good fame that really meant to incorporate himself into our society; on the other hand, I do not wish that any man should acquire the privilege but such as would be a real addition to the wealth or strength of the United States.

"If may be a question of some nicety, how far we can make our law to admit an alien to the right of citizenship, step by step; but there is no doubt we may, and ought to require residence as an essential."

\section{Mr. Smith of South Carolina spoke as follows :}

"He thought some restraints proper, and that they would tend to raise the Government in the opinion of good men, who are desirous of emigrating; as for the privilege of electing, or being elected, he conceived a man ought to be some time in the country before he could pretend to exercise it. What could he know of the Government the moment he landed? Little or nothing; how then could he ascertain who was a proper person to legislate or judge of the laws? Certainly gentlemen would not pretend to bestow a privilege upon a man which he is incapable of using?"

Mr. Jackson of Georgia was also in favor of hedging about American citizenship with proper safeguards. ${ }^{10}$

"Ibid. III0. $\quad{ }^{8} I b i d$. IIII, IIr2. $\quad$ Ibid. III2. $\quad{ }^{10}$ Ibid. III4.


"Mr. Jackson conceived the present subject to be of high importance to the respectability and character of the American name; the veneration he had for, and the attachment he had to, this country, made him extremely anxious to preserve its good fame from injury. He hoped to see the title of a citizen of America as highly venerated and respected as was that of a citizen of old Rome. I am clearly of opinion, that rather than have the common class of vagrants, paupers, and other outcasts of Europe, that we had better be as we are, and trust to the natural increase of our population for inhabitants. If the motion made by the gentleman from South Carolina should obtain, such people will find an easy admission indeed to the rights of citizenship; much too easy for the interests of the people of America. Nay, sir, the terms required by the bill on the table are, in my mind, too easy. I think, before a man is admitted to enjoy the high and inestimable privileges of a citizen of America, that something more than a mere residence among us is necessary. I think he ought to pass some time in a state of probation, and, at the end of the term, be able to bring testimonials of a proper and decent behaviour; no man, who would be a credit to the community, could think such terms difficult or indelicate: if bad men should be dissatisfied on this account, and should decline to emigrate, the regulation will have a beneficial effect; for we had better keep such out of the country than admit them into it. I conceive, sir, that an amendment of this kind would be reasonable and proper; all the difficulty will be to determine how a proper certificate of good behaviour should be obtained; I think it might be done by vesting the power in the grand jury or district courts to determine on the character of the men, as they should find it."

Mr. Page was greatly disturbed by the strict rules proposed by Mr. Jackson and others, and was apprehensive lest they build up a sort of Spanish inquisition. His views were quite similar to those which are now being expressed by opponents of the proposed new legislation to control immigration more thoroughly and safeguard the citizenship of the country through a system of registration and supervision of aliens. He said : ${ }^{11}$

"With respect to the idea of excluding bad men from the rights of citizenship, I look upon it as impracticable; hard terms of admission may exclude good men, but will not keep out one of the wretches alluded to; they will come in various forms, and care little about citizenship. If we make use of the grand jury for this purpose, as proposed by the member from Georgia (Mr. Jackson), we must, to complete the plan, authorize the grand jury to indict such emigrants as are unworthy to become citizens, and expel them. We must add an inquisition, and as it will not be sufficient for our views of having immaculate citizens, we should add censors, and banish the immoral from amongst us. Indeed, sir, I fear, if we go on as is proposed now, in the infancy of our Republic, we shall, in time, require a test of faith and politics, of every person who shall come into these States."

Mr. Stone of Maryland was among those who favored strict rules. In the debate, which was continued on March 4 th, he said: $:^{12}$

\footnotetext{
"Ibid. III4, III5.

12 Ibid. III8.
} 
"I would let the term of residence be long enough to accomplish two objects, before I would consent to admit a foreigner to have anything to do with the politics of this country. First, that he should have an opportunity of knowing the circumstances of our Government, and in consequence thereof, shall have admitted the truth of the principles we hold. Second, that he shall have acquired a taste for this kind of Government. And in order that both these things may take place, in such a full manner as to make him worthy of admission into our society, I think a term of four or seven years ought to be required."

Mr. Sedgwick of Massachusetts and Mr. Burke of South Carolina were interested not only in the question of naturalization restrictions, but in the whole citizenship problem, including the question of the restriction of immigration. It is interesting, in view of the present day discussion of this matter, to listen to these far off voices, speaking in the very dawn of our national existence. Notwithstanding the lapse of years and the changed conditions their words sound strangely modern, and the views which they expressed are quite similar to those shared by many Americans of our own times. ${ }^{13}$

"Mr. Sedgwick was against the indiscriminate admission of foreigners to the highest rights of human nature, upon terms so incompetent to secure the society from being overrun with the outcasts of Europe; besides, the policy of settling the vacant territory by emigration is of a doubtful nature. He believed, in the United States, the human species might be multiplied by a more eligible and convenient mode, than what seemed to be contemplated by the motion now before the committee. He was well satisfied for himself, that there existed no absolute necessity of peopling it in this way; and, if there was no absolute necessity, he thought Congress might use their discretion, and admit none but reputable and worthy characters; such only were fit for the society into which they were blended."

"Mr. Burke thought it of importance to fill the country with useful men, such as farmers, mechanics, and manufacturers, and, therefore, would hold out every encouragement to them to emigrate to America. This class he would receive on liberal terms; and he was satisfied there would be room enough for them, and for their posterity, for five hundred years to come. There was another class of men, whom he did not think useful, and he did not care what impediments were thrown in their way; such as your European merchants, and factors of merchants, who come with a view of remaining so long as will enable them to acquire a fortune, and then they will leave the country, and carry off all their property with them. These people injure us more than they do us good, and, except in this last sentiment, I can compare them to nothing but leeches. They stick to us until they get their fill of our best blood, and then they fall off and leave us. I look upon the privilege of an American citizen to be an honorable one, and it ought not to be thrown away upon such people."

The Naturalization Act of January 29, $1795,{ }^{14}$ contained a number of additional provisions, all in the direction of greater strictness. They

\footnotetext{
${ }^{23}$ Ibid. III7.
}

$$
{ }^{14} \text { I Stat. at L. 4r. }
$$


included a preliminary residence of five instead of two years, a formal declaration of intention at least three years before naturalization, a specific renunciation of the prior allegiance of the applicant and a renunciation of any "hereditary title" or "order of nobility" which the applicant might possess. This statute also required the applicant to show to the satisfaction of the court that during the five years immediately preceding his application, he had "behaved as a man of good moral character, attached to the principles of the constitution of the United States, and well disposed to the good order and happiness of the same."

Of the changes made by this statute the most important was the extension of the required period of residence, although the discussion in Congress, which was not in any way notable, ranged principally around the question of renunciation of prior allegiance and of titles or orders of nobility.

The preliminary period of residence may be said to have had two primary objects: first, to make it possible for the alien to learn the nature of our institutions; and second, to make it possible for the court of naturalization to ascertain, through examination of witnesses acquainted with the applicant, whether he was a fit person to receive the privilege of American citizenship. There was a third object, closely connected with the two just mentioned and quite as important as they, namely, to reduce the danger of granting naturalization and the rights accompanying it to vagrant, shifting aliens who had not taken root in our soil or really become identified with America, and who sought American citizenship merely for the advantages and protection which it conferred.

By an Act of Congress of June I8, I798,15 radical changes in the direction of strictness were made in the naturalization law. Not only was the period of residence prior to naturalization increased to fourteen years and the period between the declaration of intention and naturalization increased to five years, and a provision inserted prohibiting the naturalization of alien enemies, but a rigid system of registration of aliens was established. Aliens already in the country were required to register within six months with clerks of district courts, collectors of customs, or other officials to be designated by the President, and aliens arriving thereafter were required to register within forty-eight hours of their arrival. The registry was required "to ascertain the sex, place of birth, age, nation, place of allegiance or citizenship, condition or occupation, and place of actual or intended residence within the United States, of the alien or aliens reported."

Failure to register was punishable by fine and imprisonment.

This act also required clerks of courts naturalizing aliens to send to the Secretary of State complete reports of all declarations of intention and naturalizations.

\footnotetext{
${ }^{15} \mathrm{I}$ ibid. 566 (ch. 54).
} 
The act was passed at the time of our troubles with France and was aimed principally at French agitators in the United States. It was passed as a result of the same movement which brought about the passage of the famous Alien and Sedition. Laws, and was abolished when the revulsion of feeling came. This was unfortunate, since, although the residential period of fourteen years was probably unreasonably long, the provisions concerning registration of aliens and recording of naturalizations by the Federal Government were excellent.

The act just mentioned was replaced by the Act of April I4, I802, ${ }^{18}$ by which the fourteen-year residential period was abolished and the five-year period restored. While the recording of naturalizations in the Department of State was abandoned, the registration of aliens was retained, although in a greatly modified form. No fixed period was prescribed within which the registration should be made, and it does not seem to have been compulsory. Chief Justice Marshall, in the case of Spratt v. Spratt, ${ }^{17}$ held that it did not have to be made "within any limited time" after the arrival of the alien and might be made five years after his arrival. According to the same decision, although it was the duty of the court of naturalization to call for the certificate, its failure to do so did not necessarily nullify the naturalization. While this registration was devised partly to assist courts of naturalization in ascertaining whether applicants had resided in the United States for the required period of five years, it was probably intended, like the somewhat similar, but more drastic, provision of the Act of $1798,{ }^{18}$ for a broader purpose, namely, to furnish information concerning immigrants, their origin, nationality, and intended future residence, which might be useful to the Government in maintaining some kind of supervision of them and in shaping and applying legislation concerning immigration and naturalization. This provision seems to have contained the germ of an idea which is now the subject of much discussion. Unfortunately this plan, partly no doubt because of the vagueness of the provision, seems never to have been carried out.

Except for the extension, by the Act of Congress of July $14,1870,{ }^{10}$ of the privilege of naturalization "to aliens of African nativity, and to persons of African descent," there was no important change in the naturalization law until the passage of the Act of June $29,1906,{ }^{20}$ by which the whole naturalization system, which had theretofore been carried on in a slipshod fashion by hundreds of federal and state courts, including municipal and police courts, without co-ordination, uniformity, or federal control, was thoroughly reformed and reorganized and placed under the supervision of the Department of Commerce and Labor. This work is now carried on by the Bureau of Naturalization of the Department of Labor. I cannot undertake to discuss the provisions of

\footnotetext{
${ }^{18} 2$ Stat. at L. I53.

${ }^{18}$ Supra note 15 .

${ }^{17}$ (1830, U. S.) 4 Pet. 393.

${ }^{20}$ I6 Stat. at L. $254 . \quad{ }^{20} 34$ ibid. 596.
} 
this important act in detail. ${ }^{21}$ In brief, I may say that it provided for maintenance of complete records of all naturalizations in a central office, the Bureau of Naturalization, for uniformity of naturalization certificates, which had formerly been issued in all shapes and sizes, according to the fancy of the various courts, and for the intervention in naturalization proceedings of naturalization examiners, representing the Federal Government, in a matter so closely affecting its interests, to see that the federal statutes are observed and to safeguard the country against the naturalization frauds which had formerly been allowed to go on to such a disgraceful extent, and in which unscrupulous politicians of both parties had wallowed. This act also required an applicant to have his petition verified by affidavits of at least two credible witnesses, testifying not only to his residence in the United States, but also as to his character and fitness for naturalization. In addition it required him to file with his petition a certificate from the Department of Labor showing the "date, place, and manner of his arrival in the United States."22 Further on I shall call attention to other provisions of this act which bear a special relation to the subject of this discussion.

While Congress had from time to time been making changes in the naturalization laws the closely related questions of immigration and expatriation had, with the ever increasing flow of aliens into the United States, been engaging the attention of all three branches of the Federal Government. It is impossible, within the limits of this article, to give even a brief review of legislation and judicial decisions relating to immigration, but I wish to discuss to some extent the question of expatriation. This question has two phases, of which the first relates to the loss of foreign allegiance or protection on the part of aliens coming to this country to reside, and the second to the loss of American allegiance or protection on the part of American citizens going to foreign countries to reside. It is my purpose to deal principally with the latter question, but I shall first discuss the former.

While the United States may now be said to stand for what is known as the "right of expatriation," that is, the natural right of a person who has fulfilled his political obligations to depart from his country of origin and absolve himself from his original allegiance, upon identifying himself with another political community, through naturalization, this right was for many years denied not only by the courts of our country, which considered themselves to be bound by the old common-law, or feudal, theory of indissoluble allegiance, but also by publicists and writers on law, including Kent and Story. As Mr. John Bassett Moore has pointed out, ${ }^{23}$ the doctrine of the right of expatriation came through

${ }^{2}$ For a discussion of the various provisions of this act, see Van Dyne, Naturalization (1907).

22 Sec. 4, ss. 2 (34 Stat. at L. 596, 597).

${ }^{23}$ Principles of Anerican Diplomacy (I9I8) ch. 7 (The Doctrine of Expatriation).

While the doctrine of the right of expatriation may be said to have been 
historical development and the demands of our numerous citizens of foreign birth, who, having forsworn their original allegiance upon taking the oath of allegiance to the United States, looked to our Government to protect them from punishment or enforced performance of military service when they returned to their native lands, to visit relatives or attend to business or for other purposes. As Mr. Moore has pointed out, our controversy with Great Britain, which led up to the War of I8I2, arose, not out of the British claim to the allegiance of naturalized Americans of British origin who had voluntarily returned to British territory, but to the impressment of these men by British naval officers while they were serving on American vessels, which was equivalent to being on American territory.

I know of no more thoughtful discussion of the question of the right of expatriation than the opinion of Justice Iredell of the Supreme Court of the United States in the old case of Talbot $v$. Janson, ${ }^{24}$ decided in August I795. This case related to the capture in behalf of the French Government of a Dutch vessel by a privateer fitted out in the United States and commanded by one Ballard, an American citizen who held no commission of the French Government, but who was aided and abetted by one Talbot, a native of the United States, who had acquired a French certificate of naturalization and a commission from the French Governor of Guadeloupe. The capture was declared to be illegal, seemingly upon the ground that it was really made by Ballard, who had no claim to French nationality, but the question of Talbot's nationality was also considered. The court seems to have concluded that he was still to be considered an American citizen, never having left this country in good faith and established himself permanently in French territory.

Chief Justice Rutledge said:25

"The doctrine of expatriation is certainly of great magnitude; but it is not necessary to give an opinion upon it, in the present cause, there being no proof, that Captain Talbot's admission as a citizen of the French Republic, was with a view to relinquish his native country; and a man may, at the same time, enjoy the rights of citizenship under two governments."

arrived at in the United States through natural evolution, this doctrine was not invented in our country. According to Cicero it was recognized by the law of Rome. In his oration in defence of Balbus he made the following often quoted statement: "Ne quis invitus civitate mutetur, neve in civitate maneat invitus. Haec sunt enim fundamenta firmissima nostrae libertatis, sui quemque juris et retinendi et dimittendi esse domininm."

It appears that L. Cornelius Balbus, a friend of Julius Cæsar, was a naturalized Roman citizen of Spanish origin, having obtained Roman citizenship through a decree of Pompey of the year 72 B. C., and that, in the absence of Casar from Rome, he was indicted by the aristocratic party for illegal assumption and use of the Roman franchise. E. G. Sihler, Cicero of Arpinum (Yale Univ. Press. Igr5).

${ }^{24} 3$ Dall. I33. $\quad{ }^{25}$ Ibid. I69. 
In the course of his opinion Justice Iredell said :26

"That a man ought not to be a slave; that he should not be confined against his will to a particular spot, because he happened to draw his first breath upon it; that he should not be compelled to continue in a society to which he is accidentally attached, when he can better his situation elsewhere, much less when he must starve in one country, and may live comfortably in another; are positions which I hold as strongly as any man, and they are such as most nations in the world appear clearly to recognize."

$$
* * * * *
$$

"It is not the exercise of a natural right, in which the individual is to be considered as alone concerned. As every man is entitled to claim rights in society, which it is the duty of the society to protect; he, in his turn, is under a solemn obligation to discharge all those duties faithfully, which he owes, as a citizen, to the society of which he is a member, and as a man to the several members of the society individually with whom he is associated. Therefore, if he has been in the exercise of any public trust, for which he has not fully accounted, he ought not to leave the society until he has accounted for it."

"Some writers on the subject of expatriation say, a man shall not expatriate in a time of war, so as to do a prejudice to his country. But if it be a natural, unalienable, right, upon the footing of mere private will, who can say this shall not be exercised in time of war, as well as in time of peace, since the individual, upon that principle, is to think of himself only? I therefore think, with one of the gentlemen for the defendant, that the principle goes to a state of war, as well as peace, and it must involve a time of the greatest public calamity, as well as the profoundest tranquillity.

"The very statement of an exception in time of war, shows that the writers on the law of nations, upon the subject in general, plainly mean, not that it is a right to be always exercised without the least restraint of his own will and pleasure, but that it is a reasonable and moral right which every man ought to be allowed to exercise, with no other limitation than such as the public safety or interest requires, to which all private rights ought and must forever give way."

According to the opinion of Justice Iredell the right of expatriation, if it may properly be called a right, is a qualified right.

It is interesting to note that, in their opinions, both Justice Iredell and Justice Patterson called attention to the need of a statute of the United States relative to expatriation, but many years elapsed before such a statute was passed.

On June 17, I797, there was reported to the House of Representatives a bill "forbidding citizens of the United States from entering into the service of any foreign Prince or State in a state of war," and this bill contained, in its sixth section, a provision concerning expatriation, which read in part as follows: ${ }^{27}$

"That the citizens of the United States, whether native or adopted, shall be deemed citizens thereof, until they relinquish that character in

\footnotetext{
${ }^{28}$ Ibid. $162-163$.
}

${ }^{27}$ I Annals, 5th Cong. 350. 
manner hereinafter provided, that is to say; whensoever any citizen of the United States shall, by deed in writing, under his hand and seal, executed in the presence of, and subscribed by two or more witnesses... declare that he absolutely and entirely renounces all allegiance and fidelity to the United States, and to every of them, and shall forthwith depart out of the territorial limits thereof; every such person, from the time of his departure, if his rentuciation, verbal or written as aforesaid, shall have been duly recorded before his departure, shall be considered expatriated, and forever thereafter be deemed an alien, in like manner and to all intents as if he had never been a citizen."

In the debate which followed members of Congress were divided between those who held to the doctrine of indissoluble allegiance and those of a more liberal type who entertained a contrary view.

Mr. Sewall of Massachusetts said :28

"A man born and educated in a country certainly owed it obligations, which were not to be shaken off the moment he chose to do so. The different societies of the world, he said, were like so many families independent of each other; and what family, he asked, would suffer any of its members to leave it and go into another when they pleased? He thought it unreasonable that it should be so."

Mr. Smith of Connecticut was opposed to the expatriation provision. In the course of his speech he said $:^{29}$

"Gentlemen advocating these clauses, say they would not allow of expatriation in time of war. He would go further and say he would not allow of it when there was a prospect of war, for it is idle to prohibit .it in one case and not in the other. He then asked if this was not the very state in which we now were? If it were, why pass such a bill at this time, when it could not go into operation? He thought this a good reason for rejecting these clauses.

"There was a mutual obligation, Mr. S. said, between a Government and all its citizens. The Government owed protection to its citizens, and citizens owed obedience to their Government. These duties were mutual and co-extensive; and they might as well say that Government could abandon its citizens when it pleased as that citizens could desert their Government when they pleased. Yet he would allow that Government might, on certain occasions, legalize expatriation, but not on the ground of a citizen's having a right to expatriate when he pleased. He should have no objection to take up the subject at a time when they could do justice to it, but he thought the present was not that time."

Mr. Nicholas of Virginia, while he was opposed to the bill, believed in the right of expatriation. In the course of his speech he observed : ${ }^{30}$

"As to the doctrine of perpetual allegiance, he did not think it could find many advocates in this country. It would, indeed, be dishonorable for us to hold out such a doctrine, after inviting people to come here in crowds from foreign countries."

Mr. Gallatin of Pennsylvania was also opposed to the expatriation provision, although he believed in the right of expatriation. ${ }^{31}$
${ }^{2 s}$ Ibid.
20 Ibid. 352 .
${ }^{30}$ Ibid. 354 .
s1 Ibid. 
"With respect to expatriation, having himself exercised the right, he could not be supposed to be opposed to that right. Perpetual allegiance was too absurd a doctrine to find many advocates in this country. The question was not whether citizens had a right to expatriate, but whether they should in this law prescribe a mode of doing it. The right seemed to have been recognized by the Executive and Judiciary. He was against going into this business, because he thought it unnecessary. He believed the determination of who were citizens, and who were not, might be safely left with the Judiciary."

The provision in the foreign service bill of 1797 concerning expatriation was never enacted into law.

While the courts, with a few exceptions, were loath to depart from the common-law theory of indissoluble allegiance, ${ }^{32}$ the executive branch of the Government was more able and willing to respond to popular feeling. The great protagonist of the doctrine of the right of expatriation, as Mr. Moore points out, ${ }^{33}$ was James Buchanan, who, first as Secretary of State and later as President, came out clearly and unequivocally in favor of it. He was ably supported by Attorney-General Black, whose opinion of July 4, I859, ${ }^{34}$ concerning the case of Christian Ernst, a naturalized American citizen of Hanoverian origin who was arrested upon his return to Hanover, has become a classic on this subject. It seems worth whille to quote from this notable opinion : $:^{35}$

"The natural right of every free person, who owes no debts and is not guilty of any crime, to leave the country of his birth in good faith and for an honest purpose, the privilege of throwing off his natural allegiance and substituting another allegiance in its place-the general right, in one word, of expatriation-is incontestible. I know that the common law of England denies it; that the judicial decisions of that country are opposed to it; and that some of our own courts, misled by British authority, have expressed, though not very decisively, the same opinion. But all this is very far from settling the question. The municipal code of England is not one of the sources from which we derive our knowledge of international law. We take it from natural reason and justice, from writers of known wisdom, and from the practice of civilized nations. All these are opposed to the doctrine of perpetual allegiance. It is too injurious to the general interests of mankind to be tolerated; justice denies that men should either be confined to their native soil or driven away from it against their will."

$$
* * * * * * *
$$

"The application of these principles to the case of any naturalized citizen who returns to his native country is simple and easy enough. He is liable, like anybody else, to be arrested for a debt or a crime; but be cannot rightfully be punished for the mere non-performance of a duty which is supposed to grow out of that allegiance which he has abjured and renounced. If he was a deserter from the army, he may be punished when he goes back, because desertion is a crime. On the

\footnotetext{
${ }^{32}$ For a review of the decision see the report of Secretary of the Treasury Richardson to President Grant. 2 Foreign Relations of the United States for I873, I193-1209.

${ }^{33}$ Op. cit. 276, et seq. $\quad{ }^{34} 9$ Op. Att'y. Gen. $356 . \quad{ }^{85}$ Ibid. $357-358$.
} 
other hand, if he was not actually in the army at the time of his emigration, but merely liable, like other members of the State, to be called on for his share of military duty, which he did not perform because he left the country before the time for its performance came round, he cannot justly be molested." 36

Upon the basis of this opinion Secretary Cass, on July 8 , 1859 , sent an instruction to our Minister at Berlin, directing him to ask for the release of Ernst. In this instruction appeared the following passage: $:^{37}$

"The moment a foreigner becomes naturalized his allegiance to his native country is severed forever. He experiences a new political birth. $\mathrm{A}$ broad and impassable line separates him from his native country. $\mathrm{He}$ is no more responsible for anything he may say or do, or omit to say or do, after assuming his new character, than if he had been born in the United States. Should he return to his native country, he returns as an American citizen, and in no other character. In order to entitle his original government to punish him for an offence, this must have been committed while he was a subject and owed allegiance to that government .... It must have been of such character that he might have been tried and punished for it at the moment of his departure."

As the result of representations by the American Minister, Ernst was finally released, but the cases of naturalized Americans arrested in their native lands multiplied and became the subject of political agitation in this country. On July 7, I868, Congress, as the result of the arrest and detention in England of two naturalized Irishmen, Warren and Costello, passed the famous Joint Resolution ${ }^{38}$ in which it was declared that "the right of expatriation is a natural and inherent right of all people, indispensable to the enjoyment of the rights of life, liberty, and the pursuit of happiness," and that "all naturalized citizens of the United States, while in foreign countries, are entitled to and shall receive from this Government the same protection of persons and property which is accorded to native born citizens."

In this same year John Bancroft, our Minister to Berlin, through skilful diplomacy, concluded the celebrated treaties with the North German Union, Baden, Bavaria, Hesse, and Wuerttemberg, ${ }^{39}$ in which each contracting party engaged to recognize the naturalization by the other of the citizens or subjects of the former, provided they should have resided for five years in the territory of the country of naturalization. These treaties involved an important concession to the United States, but they contained-provisions safeguarding the German States against fraud and imposition on the part of their subjects who might procure naturalization in the United States solely for the purpose of avoiding their military duties to their native land. All of the other treaties contained stipulations to the effect that naturalization did not

${ }^{83}$ Ibid. 362 .

${ }^{37} 3$ Moore, International Law Digest (I906) 574, 575.

${ }^{38}$ Now embodied in U. S. Rev. Sts. 1878, secs. I999-200I.

${ }^{39}$ Commonly known as the "Bancroft Treaties." 
absolve the person naturalized from liability to punishment for an offence against his native country, committed before emigration, and all, except the treaty with Baden, contained provisions that if a naturalized citizen should return to his native land for permanent residence he should be held to have renounced his naturalization, and that a residence of two years would raise a presumption of permanency.

From Mr. Bancroft's despatch of January $23,1868,40$ it appears that there was an understanding between the German and British Governments with regard to the question of meeting the desires of the United States Government concerning expatriation and naturalization. The correspondence shows that the Germans, led by Count Bismarck, were more than willing to give evidence of friendship to the United States. It is an interesting fact that the original draft of the treaty, which was only slightly changed before signature, was actually prepared by the Germans. ${ }^{41}$ The treaty was signed on February 22, and on the same day Mr. Bancroft sent a despatch to the Secretary of State, from which I quote the following paragraphs:

"I hold it of good augury that the treaty between the United States and North Germany respecting the effect of naturalization has been signed on Washington's birthday.

"Immediately upon entering upon my office I gave attention to this subject, respecting which your instructions were so full as to leave nothing to desire.

"I was met in the most friendly spirit. If we had followed the standard books on international law we could have come to no result, for they fail in the great point of the right of the naturalized citizen to maintain his new citizenship in his old country. The opinions of the lawyers of the United States are, as you so well know, in conflict with each other. The laws in Prussia and in the United States, interpreter according to the letter, were also in conflict. To succeed, it was necessary, to consider the principles underlying the laws of the two countries; and here there was found to be a remarkable harmony. . .

".... Count Bismarck from the first took a large and liberal view of the case. But with all this, the difficulties were numerous and grave. I made it my rule throughout to avoid controversy and not to precipitate a decision.

"On the question of the right of expatriation there arose no discussion. It is recognized by the laws of both countries.

"On the question of residence as a condition of naturalization which the mother country should respect, there existed no difference.

"The time of residence was a point of more delicacy. The Prussian law required an absence of Io years; ours a residence of five. With . liberality and frankness Count Bismarck declared himself willing to accept the American rule, as it had received the sanction of the administration of Washington, and had become fixed by the usage of more than three score years and ten."

${ }^{40}$ The correspondence between Mr. Bancroft and Secretary of State Seward in regard to the negotiations leading up to the treaty with the North German Union is printed in 2 Diplomatic Correspondence for $1868,40-59$.

${ }^{41}$ See enclosure to Mr. Bancroft's despatch, No. 4I, of Feb. I4, I869. 
"A question has arisen at what time the emigrant shall be released from liability to military service, whether from the moment of his emigration, or of his naturalization. The object of this government is a real, permanent, friendly adjustment of all questions that have been raised, and it has therefore in the $2 \mathrm{~d}$ article agreed that the emigrant, on his return, shall not be called to account for the non-performance of any military duty to which the liability may arise subsequent to his emigration."

"I trust the President and Senate will unanimously approve what I have done, and that the ratification of the treaty herewith enclosed will be immediately returned for the necessary exchange. The result is to be ascribed to the hereditary disposition of this government, unaltered from the days of the great Frederick and Franklin, to cherish the best relations with us; and to the mutual desire that the first important transaction between the United States of America and the United States of North Germany may bear indelible marks of a disposition to recognize and perpetuate the natural friendship of the two countries."

On November 20, I868, Mr. Bancroft wrote to the Secretary of State concerning the rumors of war between Germany and France. He showed why it was to the interest of the United States to do whatever might be possible to prevent such a catastrophe. He remarked, however, that, "there is now a lull in the rumors of war, and they will not very soon be renewed." His judgment as to the disastrous nature of the threatened war was better than his prophesy as to its imminence. There may have been some connection between the impending war and the remarkably conciliatory attitude of Bismarck toward the United States with reference to the naturalization treaty.

Shortly after the conclusion of the Bancroft Treaties, the United States concluded treaties of naturalization with Austria-Hungary, Belgium, Denmark, Great Britain, and Sweden and Norway. Of these the convention with Great Britain, concluded May I3, I870, was perhaps the most important, in view of the controversies which preceded it concerning the status of naturalized American citizens of British origin who returned to Great Britian. ${ }^{42}$ The provisions of this convention were extremely liberal. There was no stipulation as to length of residence in the country of naturalization, nor were there any provisions concerning liability to punishment for offences committed before emigration or concerning a presumption of renunciation of naturalization on the part of persons returning to their native land to reside. This liberality seems to have been due partly to a desire to settle all controversies between the two countries, including the Alabama Claims controversy, and partly to the very. liberal report of the commission

\footnotetext{
${ }^{12}$ Lord Cockburn, in his book published in I869 entitled Nationality, argues with some reason that the cases about which the Government of the United States protested to the British Government did not have much merit in themselves, since they related to naturalized Irishmen who returned to their native land to take part in the Fenian organization.
} 
appointed by the Queen on May 21, I868, "for enquiring into laws of naturalization and allegiance." This commission was composed of ten members, including the Earl of Clarendon, Sir Robert Phillimore, Sir Travers Twiss, Sir Roundell Palmer, and Mr. Vernon Harcourt. It made an exhaustive study of the nationality laws of all countries, and submitted its report on February 20, I869. In it appears the following very important statement: ${ }^{43}$

"The allegiance of a natural-born British subject is regarded by the common law as indelible.

"We are of opinion that this doctrine of the common law is neither reasonable nor convenient. It is at variance with those principles on which the rights and duties of a subject should be deemed to rest; it conflicts with that freedom of action which is now recognized as most conducive to the general good as well as to individual happiness and prosperity; and it is especially inconsistent with the practice of a State which allows to its subjects absolute freedom of emigration. It is inexpedient that British law should maintain in theory, or should by foreign nations be supposed to maintain in practice, any obligations which it cannot enforce and ought not to enforce if it could; and it is unfit that a country should remain subject to claims for protection on the part of persons who, so far as in them lies, have severed their connection with it."

The committee advised against inserting in the British law a provision to the effect that "acquisition of a foreign domicile, or a certain length of residence abroad should divest a person of British nationality." The committee in making the latter recommendation said that it had "regard to the difficulties which attend the definitions of domicile and proof of the fact, and also to the great diversity of circumstances under which men reside in foreign countries."

The report of the committee was followed by the passage of the British Naturalization Act of May 12, $1870,{ }^{44}$ section 6 of which provided as follows:

"Any British subject who has at any time before, or may at any time after the passing of this act, when in any foreign state and not under any disability, voluntarily become naturalized in such state, shall, from and after the time of his so having become naturalized in such foreign state, be deemed to have ceased to be a British subject and be regarded as an alien."

Section 4 of the Naturalization Act contained a provision under which a "declaration of alienage" might be made by a person born in

A copy of this report may be found in 2 Foreign Relations of The United States for 1873, 1232, 1234, et seq. As the report itself shows, the appointment of this committee was due to the desire of the British Government to settle controversies with the United States arising out of conflicts in the laws of nationality of the two countries.

"This statute is printed in the report of the board appointed by the Acting Secretary of State of the United States, July 3, I906, to make a study of citizenship questions. House Doc. 326, 59th Cong., 2 d Sess. 333, et seq. 
British territory of an alien father or by a person born abroad of a British father.

In I902 a naturalization convention was concluded with Haiti, and between 1908 and r9II naturalization conventions were concluded with Brazil, Costa Rica, Nicaragua, Honduras, Peru, Portugal, Salvador, and Uruguay: On August I3, Igo6, there was signed at Rio de Janeiro a convention between the United States and most of the Latin American countries, ${ }^{45}$ in which it was provided that if a citizen born in one of these countries and naturalized in another returns to reside permanently in his native land, "he will be considered as having re-assumed his original citizenship, and as having renounced the citizenship acquired by the said naturalization." It was further provided that a residence of two years should raise a rebuttable presumption of permanency. This was to all intents and purposes a naturalization convention, since it recognized the fact that naturalization resulted in a loss of the original nationality.

The United States has not yet succeeded in concluding naturalization conventions with the majority of European countries, including France, Italy, Greece, The Netherlands, Spain, the Balkan countries, Russia, or Turkey. ${ }^{46}$ Such conventions furnish the only satisfactory means of settling controversies arising from cases of naturalized citizens who return to sojourn or reside in their native lands. By prescribing fair and definite rules for the settlement of these vexatious cases naturalization conventions are of advantage to the countries of origin as well as to the countries of naturalization.

Whatever views one may entertain concerning the right of expatriation as a political theory, and much may be said and has been said on both sides of the question, the fact remains that the United States has for many years definitely stood for this right, although with reasonable

${ }^{4}$ Columbia, Chile, Costa Rica, Nicaragua, Guatemala, Brazil, Mexico, Ecuador, Honduras, Panama, Salvador, and Argentina.

${ }^{16}$ Under Article I7 of the French Civil Code a Frenchman loses his French nationality by becoming naturalized abroad only upon the condition that his military obligations have been fulfilled or that he has obtained the permission of the French Government.

Article 8 of the Italian Law of Nationality of June 13, I912, which provides that Italian nationality is lost by naturalization and the establishment of a residence abroad, also, rather inconsistently, provides that such loss of nationality gives no exemption from the obligations of military service. This applies to obligations accruing after, as well as to those accruing before, emigration.

Under Article 3 of the Netherlands Law of Nationality of December 12, I892, Netherlands nationality is lost by naturalization abroad. Article 20 of the Spanish Civil Code and Article I7 of the Roumanian Civil Code contain similar provisions.

Article 16 of the Bulgarian Civil Code is similar to Article I7 of the French Code.

Under Articles 7 and 8 of the Servian Civil Code of I844, a Servian, before acquiring naturalization abroad, was required to obtain from the Servian Minister 
qualifications in favor of the just demands of the countries of origin. ${ }^{47}$ The only practical way of arriving at a satisfactory solution of the problem is to view it, not as an abstract proposition, but as an incident in the advancement of mankind everywhere toward freedom, and general recognition of the principle that men are not made for governments but governments for men. This view is reflected in the opinions of Justice Iredell and Attorney-General Black and the report of the British Committee of 1870 , from which I have quoted above. As we have seen, the insistence of the United States Government upon the broad right of expatriation resulted to an important extent in changing the attitude of Great Britain and other countries toward this subject.

(To be concluded)

of the Interior a certificate of manumission or of emigration, upon submission of proof that he had acquitted himself of all of his obligations in the country, not only to the state or the commune, but even to individuals.

The law of the Russian Empire required Russians to obtain the express permission of the Russian Government before obtaining naturalization abroad. Article 325 of the Penal Code provided that the violation of this requirement should be punishable by forfeiture of property rights and perpetual banishment. $I$ am not informed whether this law is still in effect.

Article 5 of the Ottoman Law of Nationality of 1869 provided that an Ottoman subject did not lose his original allegiance by naturalization abroad unless he had obtained permission through an imperial irade.

"A recognition of reasonable qualification of the right of expatriation, in favor of the country of origin, does not necessarily involve abandonment of the principle altogether. "The principle," say W. B. Lawrence, "is, in nowise, affected by requiring the emigrant not to leave his native land, without discharging antecedent obligations." Wheaton, International Law (Lawrenco's ed.) 919. 